\title{
The Shanghai Global Ranking of Academic Subjects: Room for improvement
}

\author{
Erwin Krauskopf
}

How to cite this article:

Krauskopf, Erwin (2021). "The Shanghai Global Ranking of Academic Subjects: Room for improvement". Profesional de la información, v. 30, n. 4, e300408.

https://doi.org/10.3145/epi.2021.jul.08

Manuscript received on $12^{\text {th }}$ April 2021 Accepted on $19^{\text {th }}$ May 2021

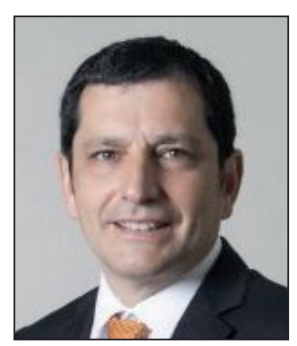

\author{
Erwin Krauskopf $\square$ \\ https://orcid.org/0000-0002-4082-5758 \\ Universidad de Las Américas \\ Vicerrectorado de Investigación \\ Avenida Manuel Montt 948, Providencia \\ Santiago de Chile, Chile \\ ekrauskopf@udla.cl
}

\begin{abstract}
Global university rankings have achieved public popularity as they are portrayed as an objective measure of the quality of higher education institutions. One of the latest rankings is the Shanghai Global Ranking of Academic Subjects, which classifies institutions according to five fields -Engineering, Life Sciences, Medical Sciences, Natural Sciences and Social Sciences- which are divided into 54 subjects. Despite being introduced in 2017, no study has analyzed the methodology applied by this ranking. The results of our analysis show that the methodology currently used by the Shanghai Global Ranking of Academic Subjects presents several issues, which negatively affect a large proportion of universities around the world. Needless to say, if the Shanghai Global Ranking of Academic Subjects is meant to be global, it needs to expand its surveys to countries located in the Global South.
\end{abstract}

\section{Keywords}

ARWU; Shanghai Ranking; Academic subjects; Categories; WoS; JCR; Topics; Issues; Disciplines; Rankings; Classifications; Universities; Higher Education; Institutions; Bibliometrics; Research performance; Research evaluation; Critical perspective; Flaws; Indicators; Global South.

\section{Introduction}

Global university rankings have achieved public popularity as they are portrayed as an objective measure of the quality of higher education institutions. Not surprisingly, prospective students ponder the information published by these rankings as they search for a place to continue their education (Krauskopf, 2013). This is not a current trend, as for over ten years these rankings have influenced, on different levels, the final decision of prospective students (Sauder; Espeland, 2009). In fact, González-Riaño, Repiso and Delgado-López-Cózar (2014) showed that the media, in particular newspapers, take note of these rankings, bringing them closer to citizens, hence increasing their impact.

Despite their widespread use, global university rankings have not been without controversy. As early as 2005, VanRaan (2005) described methodological problems in ranking universities using bibliometric methods, identifying issues such as language bias that still persist until today. A later study by Marginson and Van-der-Wende (2007) expressed their concern with the use of these global university rankings as they were being utilized for comparative purposes, while not considering the uniqueness of their mission (Marginson; Van-der-Wende, 2007; Pusser; Marginson, 2013). In fact, to maximize their institu-

Global university rankings have achieved public popularity as they are portrayed as an objective measure of the quality of higher education institutions, but despite their widespread use, global university rankings have not been without controversy 
tional ranking position, some universities may wander from their own mission (Van-der-Wende; Westerheijden, 2009; Fauzi et al., 2020). Another issue that has been raised by some studies is the weightings given to each indicator (Kehm, 2014; Olcay; Bulu, 2017). Furthermore, while many of these indicators are built on hard data (i.e., research productivity), some are based on soft data (i.e., reputation surveys), which make these indicators subjective to bias (Williams; VanDyke, 2008; Marginson, 2014).

Among the various global rankings is the Shanghai Academic Ranking of World Universities (ARWU), which was first issued in June 2003. This ranking is based on six indicators:

- "Alumni" that considers alumni of an institution winning Nobel prizes and Fields medals;

- "Award" which considers the total number of the staff of an institution winning Nobel Prizes and Fields medals;

- "N \& S" that considers the number of papers published in Nature and Science;

- " $\mathrm{HICl}$ " which considers the number of highly cited researchers of the institution;

- "PUB" which corresponds to the number of papers indexed in Science Citation Index-Expanded and Social Sciences Citation Index, and

- "PCP" that considers the weighted scores of the above five indicators divided by the number of full-time equivalent academic staff.

In 2017, the Shanghai Global Ranking of Academic Subjects was introduced, which covered 54 academic subjects among five categories: Natural Sciences, Engineering, Life Sciences, Medical Sciences and Social Sciences. The methodology used to build this ranking is based on slightly different indicators:

http://www.shanghairanking.com/Shanghairanking-Subject-Rankings/Methodology-for-ShanghaiRanking-GlobalRanking-of-Academic-Subjects-2020.html

Q1: Number of papers authored by an institution in an academic subject in journals ranked Q1 according to their impact factor, during a 5-year period (2014-2018). Only type of documents considered are "articles". Data is collected from Web of Science and InCites.

$\mathrm{CNCl}$ : Category Normalized Citation Impact is the ratio of citation of papers published by an institution in an academic subject during the 5 -year period to the average citations of papers in the same category of the same year and same type. Only "article" document-type is considered. Data is collected from InCites database.

IC: International collaboration is the number of publications that have been found with at least two different countries in addresses of the authors divided by the total number of publications in an Academic Subject for an institution during the 5-year period. Only "article" document-type is considered.

TOP: is the number of papers published in top journals in an academic subject for an institution during the 5-year period. Top journals are identified through Shanghai Rankings's Academic Excellence Survey or by Journal Impact Factor. In case no journals are identified by the survey, the top $20 \%$ journals of the Journal Citation Reports (JCR) subject category are selected. Only "article" document-type is considered.

AWARD: refers to the total number of the staff of an institution wining a significant award in an academic subject since 1981. The significant awards in each subject are identified through an Academic Excellence Survey. Applicable to staff that work full-time at an institution at the time of winning the prize.

While several studies have discussed controversial issues with the ARWU methodology and criteria that affect its results and reproducibility (Florian, 2007; Billaut; Bouyssou; Vincke, 2010; Pandiella-Dominique et al., 2018; Fernández-Cano et al., 2018; Fernández-Tuesta et al., 2019; Fauzi et al., 2020), none have questioned the methodology used by the Shanghai Global Ranking of Academic subjects. Thus, the objective of this study is to attract attention to some issues identified in the methodology used by the Shanghai Global Ranking of Academic Subjects that limit its effectiveness as a global ranking.

\section{Methodology}

Data was extracted from Web of Science (WoS) and InCites for the 2014-2018 time-period and analyzed using excel. In addition, the Classification of Web of Science categories into Academic Subjects was downloaded from http://www.shanghairanking.com/Shanghairanking-Subject-Rankings/attachment/Mapping_between_Web_of_ Science_categories_and_54_academic_subjects.pdf

The list of the top journals and conference was downloaded from http://www.shanghairanking.com/subject-survey/top-journals.html

The Shanghai Ranking's Academic Excellence Survey was downloaded from http://www.shanghairanking.com/subject-survey/index.html
In 2017, the Shanghai Global Ranking of Academic Subjects was introduced, which covered 54 academic subjects among five categories: Natural Sciences, Engineering, Life Sciences, Medical Sciences and Social Sciences 
The list of the significant awards in each subject was obtained from http://www.shanghairanking.com/subject-survey/awards.html

The list of WoS Research areas was downloaded from the following URL:

https://images.webofknowledge.com/images/help/WOS/hp_research_areas_easca.html

\section{Results and discussion}

\subsection{Academic subjects}

The Shanghai Global Ranking of Academic Subjects provides information on 54 academic subjects that are grouped into one of five research fields. In order to create these academic subjects, the creators of this ranking generated an equivalency table which contains a list of academic subjects and WoS categories. Though this list is a valuable guide towards understanding how each academic subject breaks down, it also reflects some imbalances. For instance, while the academic subject of Clinical Medicine gathers 31 WoS categories, the academic subject of Oceanography is made up of just one WoS category.

The creators of this ranking generated an equivalency table which contains a list of academic subjects and WoS categories, but it reflects some imbalances. For instance, while the academic subject of Clinical Medicine gathers 31 WoS categories, the academic subject of Oceanography is made up of just one WoS category

What is puzzling is the fact that 57 WoS categories have not been considered by the Shanghai Global Ranking of Academic Subjects. As Table 1 shows, the vast majority of these WoS categories belong either to Arts \& Humanities or Social Sciences. Since this ranking is based on bibliometric data, one could argue that perhaps the number of articles published in these categories is not significant. However, this is not the case. To illustrate this, a total of 69,729 articles were published by researchers in the WoS category of History between 2014-2018, compared to 35,842 articles published in Oceanography. Moreover, 14 WoS categories which have not been considered by the Shanghai Global Ranking of Academic Subjects (Table 1), have published more articles that Oceanography in the same time period.

Table 1. List of Web of Science categories and research areas. For each Web of Science category, the total number of documents (Total docs), articletype documents (Total articles), highly cited papers (Total HCP) is provided. \% Articles stands for the proportion of article-type documents while \% HCP represents the proportion of highly cited papers. Data was collected for the 2014-2018 time period.

\begin{tabular}{|c|c|c|c|c|c|c|}
\hline WoS categories & WoS research areas & $\begin{array}{l}\text { Total } \\
\text { docs. }\end{array}$ & $\begin{array}{c}\text { Total } \\
\text { articles }\end{array}$ & Total HCP & $\%$ Articles & $\% \mathrm{HCP}$ \\
\hline Agricultural Economics \& Policy & Life Sciences \& Biomedicine & 8,066 & 7,361 & 20 & $91.3 \%$ & $0.2 \%$ \\
\hline Agricultural Engineering & Life Sciences \& Biomedicine & 19,920 & 19,004 & 199 & $95.4 \%$ & $1.0 \%$ \\
\hline Anthropology & Social Sciences & 38,642 & 20,434 & 60 & $52.9 \%$ & $0.2 \%$ \\
\hline Archaeology & Social Sciences & 26,624 & 18,266 & 15 & $68.6 \%$ & $0.1 \%$ \\
\hline Architecture & Arts \& Humanities & 54,831 & 42,522 & 285 & $77.6 \%$ & $0.5 \%$ \\
\hline Art & Arts \& Humanities & 37,745 & 17,639 & 0 & $46.7 \%$ & $0.0 \%$ \\
\hline Asian Studies & Arts \& Humanities & 16,342 & 7,691 & 1 & $47.1 \%$ & $0.0 \%$ \\
\hline Classics & Arts \& Humanities & 14,152 & 5,521 & 0 & $39.0 \%$ & $0.0 \%$ \\
\hline Cultural Studies & Social Sciences & 11,956 & 8,644 & 19 & $72.3 \%$ & $0.2 \%$ \\
\hline Dance & Arts \& Humanities & 8,004 & 1,727 & 0 & $21.6 \%$ & $0.0 \%$ \\
\hline Demography & Social Sciences & 8,771 & 6,830 & 28 & $77.9 \%$ & $0.3 \%$ \\
\hline Development Studies & Social Sciences & 14,232 & 12,136 & 126 & $85.3 \%$ & $0.9 \%$ \\
\hline Engineering. Geological & Technology & 26,817 & 25,303 & 90 & $94.4 \%$ & $0.3 \%$ \\
\hline Engineering. Industrial & Technology & 29,368 & 26,834 & 240 & $91.4 \%$ & $0.8 \%$ \\
\hline Engineering. Multidisciplinary & Technology & 267,295 & 244,338 & 1,236 & $91.4 \%$ & $0.5 \%$ \\
\hline Ethics & Social Sciences & 20,135 & 13,428 & 54 & $66.7 \%$ & $0.3 \%$ \\
\hline Ethnic Studies & Social Sciences & 8,788 & 5,687 & 17 & $64.7 \%$ & $0.2 \%$ \\
\hline Family Studies & Social Sciences & 18,024 & 15,308 & 68 & $84.9 \%$ & $0.4 \%$ \\
\hline Film, Radio, Television & Arts \& Humanities & 22,831 & 7,441 & 2 & $32.6 \%$ & $0.0 \%$ \\
\hline Folklore & Arts \& Humanities & 3,942 & 1,642 & 0 & $41.7 \%$ & $0.0 \%$ \\
\hline Green \& Sustainable Science \& Technology & Life Sciences \& Biomedicine & 60,763 & 50,792 & 1,404 & $83.6 \%$ & $2.3 \%$ \\
\hline History & Arts \& Humanities & 171,835 & 69,729 & 38 & $40.6 \%$ & $0.0 \%$ \\
\hline History \& Philosophy of Science & Arts \& Humanities & 23,590 & 13,335 & 34 & $56.5 \%$ & $0.1 \%$ \\
\hline History of Social Sciences & Arts \& Humanities & 11,061 & 5,838 & 1 & $52.8 \%$ & $0.0 \%$ \\
\hline
\end{tabular}




\begin{tabular}{|c|c|c|c|c|c|c|}
\hline WoS categories & WoS research areas & $\begin{array}{l}\text { Total } \\
\text { docs. }\end{array}$ & $\begin{array}{c}\text { Total } \\
\text { articles }\end{array}$ & Total HCP & $\%$ Articles & $\%$ HCP \\
\hline Humanities, Multidisciplinary & Arts \& Humanities & 99,418 & 43,205 & 1 & $43.5 \%$ & $0.0 \%$ \\
\hline Language \& Linguistics & Social Sciences & 57,331 & 40,346 & 20 & $70.4 \%$ & $0.0 \%$ \\
\hline Linguistics & Social Sciences & 71,016 & 50,801 & 45 & $71.5 \%$ & $0.1 \%$ \\
\hline Literary Reviews & Arts \& Humanities & 38,257 & 10,257 & 0 & $26.8 \%$ & $0.0 \%$ \\
\hline Literary Theory \& Criticism & Arts \& Humanities & 10,958 & 6,459 & 0 & $58.9 \%$ & $0.0 \%$ \\
\hline Literature & Arts \& Humanities & 96,978 & 46,872 & 1 & $48.3 \%$ & $0.0 \%$ \\
\hline Literature, African, Australian, Canadian & Arts \& Humanities & 3,555 & 1,130 & 0 & $31.8 \%$ & $0.0 \%$ \\
\hline Literature, American & Arts \& Humanities & 5,095 & 2,364 & 0 & $46.4 \%$ & $0.0 \%$ \\
\hline Literature, British Isles & Arts \& Humanities & 4,702 & 2,121 & 0 & $45.1 \%$ & $0.0 \%$ \\
\hline Literature, German, Dutch, Scandinavian & Arts \& Humanities & 5,801 & 2,612 & 0 & $45.0 \%$ & $0.0 \%$ \\
\hline Literature, Romance & Arts \& Humanities & 28,914 & 12,259 & 0 & $42.4 \%$ & $0.0 \%$ \\
\hline Literature, Slavic & Arts \& Humanities & 5,408 & 3,026 & 0 & $56.0 \%$ & $0.0 \%$ \\
\hline Logic & Technology & 5,549 & 5,197 & 0 & $93.7 \%$ & $0.0 \%$ \\
\hline Mathematics, Interdisciplinary Applications & Technology & 57,065 & 54,361 & 443 & $95.3 \%$ & $0.8 \%$ \\
\hline Mechanics & Technology & 117,974 & 114,372 & 862 & $96.9 \%$ & $0.7 \%$ \\
\hline Medical Ethics & Life Sciences \& Biomedicine & 7,453 & 4,275 & 9 & $57.4 \%$ & $0.1 \%$ \\
\hline Medicine, Legal & Life Sciences \& Biomedicine & 13,205 & 10,296 & 11 & $78.0 \%$ & $0.1 \%$ \\
\hline Medieval \& Renaissance Studies & Arts \& Humanities & 18,157 & 6,504 & 0 & $35.8 \%$ & $0.0 \%$ \\
\hline Multidisciplinary Sciences & & 418,444 & 354,430 & 8,025 & $84.7 \%$ & $1.9 \%$ \\
\hline Music & Arts \& Humanities & 36,129 & 10,614 & 0 & $29.4 \%$ & $0.0 \%$ \\
\hline Philosophy & Arts \& Humanities & 85,378 & 53,793 & 36 & $63.0 \%$ & $0.0 \%$ \\
\hline Poetry & Arts \& Humanities & 7,335 & 886 & 0 & $12.1 \%$ & $0.0 \%$ \\
\hline Quantum Science \& Technology & Technology & 11,270 & 10,809 & 52 & $95.9 \%$ & $0.5 \%$ \\
\hline Regional \& Urban Planning & Social Sciences & 16,370 & 13,350 & 247 & $81.6 \%$ & $1.5 \%$ \\
\hline Religion & Arts \& Humanities & 75,649 & 33,267 & 2 & $44.0 \%$ & $0.0 \%$ \\
\hline Social Issues & Social Sciences & 16,918 & 10,644 & 35 & $62.9 \%$ & $0.2 \%$ \\
\hline Social Sciences, Interdisciplinary & Social Sciences & 66,914 & 54,316 & 205 & $81.2 \%$ & $0.3 \%$ \\
\hline Social Sciences, Mathematical Methods & Social Sciences & 13,748 & 12,488 & 114 & $90.8 \%$ & $0.8 \%$ \\
\hline Social Work & Social Sciences & 20,451 & 16,145 & 50 & $78.9 \%$ & $0.2 \%$ \\
\hline Sport Sciences & Life Sciences \& Biomedicine & 78,489 & 48,067 & 189 & $61.2 \%$ & $0.2 \%$ \\
\hline Theater & Arts \& Humanities & 12,041 & 5,451 & 0 & $45.3 \%$ & $0.0 \%$ \\
\hline Urban Studies & Social Sciences & 23,426 & 19,008 & 249 & $81.1 \%$ & $1.1 \%$ \\
\hline Women's Studies & Social Sciences & 15,336 & 9,750 & 22 & $63.6 \%$ & $0.1 \%$ \\
\hline
\end{tabular}

Perhaps these WOS categories are excluded because the proportion of published articles is low in comparison to other document types? As the ranking methodology indicates, only article-type documents are considered to estimate the four indicators (Q1, CNCl, IC and TOP) based on bibliometric data, with an exception in the subject of Pharmacy \& Pharmaceutical Sciences, which also considers review-type documents for the assessment of the TOP indicator. Nevertheless, this is not the case as 31 WoS categories have preferentially used article (>60\%) over any other document type as shown in Table 1. But leaving aside the quantity of articles published, various journals publish important article-type "letters" that go well beyond the response to a recently published article (Van-Raan, 2005). Other document types such as reviews, editorial material and even meeting abstracts are not only important for knowledge dissemination, but some of them have been highly cited (Krauskopf, 2011; Van-Leuween et al., 2013). In addition to this, many research areas use other research outputs that have an impact on society. In fact, the Declaration on Research Assessment (DORA) emphasizes that outputs, other than articles, will grow in importance in the near future (DORA, 2015).

Maybe the exclusion of WoS categories relates to a lack of participants in certain disciplines? After examining the academic subject associated to each participant surveyed, I noticed that three academic subjects (Biotechnology, Instrument Science \& Technology, and Telecommunication Engineering) that have been evaluated by this ranking did not register participants. Thus, the question remains on the criteria used to exclude some WoS categories.

It is puzzling that 57 WoS categories have not been considered by the Shanghai Global Ranking of Academic Subjects 
Another option might be that these WoS categories are not considered appealing enough to the people and institutions that consult university rankings in search for information about the quality of an institution. However, it is hard to believe that research on Green \& Sustainable Science \& Technology may not be of interest at a time when there is a widespread interest in sustainable development worldwide. Actually, this interest prompted the promulgation of 17 sustainable development goals (SDGs) by the United Nations, aimed at improving the sustainability of global economic and social development, while protecting the environment (Wiesmann; Dayer, 2019). Moreover, among the 17 SDGs, one refers to the topic of gender equality and women empowerment, issue that has been raised for many years by various studies (Kabeer, 2005; Ridgeway, 2011; Stoet; Geary, 2018). Nevertheless, the WoS category of Women's studies is one of the 57 that has not been incorporated into the Shanghai Global Ranking of Academic Subjects. Hence, there is clearly an obvious need to inform the criteria used to exclude some WoS categories from this ranking.

\subsection{Use of different indicators}

This issue relates to the process used to determine the number of indicators utilized to evaluate an academic subject. One would expect that all the academics subjects that were grouped under a common research area would be assessed by the same group of indicators. However, this is not the case. As an example, the research area of Life Sciences reunites four academic subjects, of which two (Biological Sciences and Human Biological Sciences) were assessed using five indicators, one (Veterinary Sciences) was evaluated based on four indicators and one utilizing just three indicators (Agricultural Sciences). In total, 21 academic subjects were assessed using four indicators and eight academic subjects using three indicators. The two indicators that were not considered for all academic subjects were the Top journal and Top awards. Since these indicators were based on the answers provided by the participants of the survey, the information provided by the participants was analyzed. By cross-referencing the eight academic subjects that only used three indicators, with the disciplines registered by the 736 participants, one can immediately notice five correspondences (Agricultural Sciences, Food Science \& Technology, Medical Technology, Oceanography and Transportation Science \& Technology) among them. Consequently, one expected that at least one journal would be selected for the Top journal indicator. -For illustrative purposes, nine academics associated to Agricultural Sciences responded the survey, but no journal was chosen as a Top journal. In this case one could hypothesize that no agreement was reached as, according to the selection criteria, a journal not only needs more than one vote in an academic subject, but it must have received more than $50 \%$ of the votes or have been selected in 2019. Contrarily, for five academic subjects (Food Science \& Technology, Marine/Ocean Engineering, Mining \& Mineral Engineering, Oceanography and Public Administration) only two participants filled the survey, yet for three of these academic subjects the Top journal indicator was weighted heavily into the formula. Thus, the lack of clarity in the procedure utilized to allocate indicators (and different weights) to each academic subject needs to be addressed.

\subsection{Shanghai Ranking's Academic Excellence Survey}

Every year hundreds of academics fill out the Shanghai Ranking's Academic Excellence Survey with the purpose of identifying the top tier journals in their research areas as well as the most influential and credible international awards. In the area of Computer Science \& Engineering, academics are also asked to name top tier conferences in the subject. In order to count a journal as a Top journal it must have been selected by at least two votes and it ought to have $50 \%$ or more of the votes or had been selected in the previous year by the participants. A similar criterion has been used to define the Top awards.

The matter in question with the survey is that it was limited to very few countries, fifteen in total. As Table 2 shows, it lacks participants from the Global South, as the surveyed academics were mainly from Europe, Asia and North America. While the only exception was Australia, the contributions of researchers from the developing world was not considered even though this ranking is meant to be global. Many studies have described in-

equalities in publication achievement of academics depending on their geographical location (Van-der-Stocken, 2016; Snowball; Shackleton, 2018; Ordóñez-Matamoros et al., 2020). Without realizing, a language-bias has been instated in this ranking as not only the majority of the participants that filled-out the survey come from Anglo-Saxon countries, but WoS also has an English-language bias (Van-Leuween et al., 2001; Mongeon; Paul-Hus, 2015). In point of fact, 94.7\% of the documents registered by WoS between 2014-2018 were in English language. Consequently, these limitations raise a question as to whether the Shanghai Global Ranking of Academic Subjects is applying a fair assessment of all higher education institutions. Thus, it is of the uttermost importance to bring researchers from the Global South out of the shadows (Rochmyaningsih, 2018). 
Table 2. Number of participants that answered the survey, by academic subject. "EG" represents Engineering; "LS" stands for Life Sciences; "MS" represents Medical Sciences; "NS" stands for Natural Sciences, and "SS" represents Social Sciences.

\begin{tabular}{|c|c|c|c|}
\hline $\begin{array}{l}\text { Research } \\
\text { area }\end{array}$ & Academic subject & \# Participants & Countries \\
\hline \multirow[t]{2}{*}{ EG } & Aerospace Engineering & 6 & Australia, United States \\
\hline & Agricultural Economics & 4 & United States \\
\hline \multirow[t]{2}{*}{ LS } & Agricultural Sciences & 9 & Australia, Canada, Finland, Germany, Switzerland \\
\hline & Archaeology & 1 & Australia \\
\hline NS & Atmospheric Science & 6 & Australia, Switzerland, United States \\
\hline \multirow[t]{2}{*}{ EG } & Automation \& Control & 11 & Australia, Belgium, Switzerland, United States \\
\hline & Bioethics and Health Policy & 1 & United States \\
\hline LS & Biological Sciences & 31 & $\begin{array}{l}\text { Australia, Canada, Finland, Germany, Switzerland, United Kingdom, } \\
\text { United States }\end{array}$ \\
\hline EG & Biomedical Engineering & 17 & $\begin{array}{l}\text { Australia, Canada, Germany, Singapore, Switzerland, United Kingdom, } \\
\text { United States }\end{array}$ \\
\hline SS & Business Administration & 16 & $\begin{array}{l}\text { Australia, Canada, Finland, Germany, Netherlands, Singapore, Switzerland, } \\
\text { United Kingdom, United States }\end{array}$ \\
\hline EG & Chemical Engineering & 25 & $\begin{array}{l}\text { Australia, Belgium, China, Germany, Singapore, Switzerland, United King- } \\
\text { dom, United States }\end{array}$ \\
\hline NS & Chemistry & 35 & $\begin{array}{l}\text { Australia, Belgium, Canada, China, Germany, Japan, Switzerland, United } \\
\text { Kingdom, United States }\end{array}$ \\
\hline EG & Civil Engineering & 15 & Australia, China, Germany, Singapore, United Kingdom,United States \\
\hline MS & Clinical Medicine & 13 & Australia, Belgium, Germany, United Kingdom, United States \\
\hline SS & Communication & 9 & China, Germany, United States \\
\hline EG & Computer Science \& Engineering & 46 & $\begin{array}{l}\text { Australia, China, Finland, Germany, Singapore, Switzerland, United King- } \\
\text { dom, United States }\end{array}$ \\
\hline MS & Dentistry \& Oral Sciences & 10 & Canada, Singapore, United Kingdom, United States \\
\hline NS & Earth Sciences & 24 & $\begin{array}{l}\text { Australia, Belgium, China, Finland, Switzerland, United Kingdom, United } \\
\text { States }\end{array}$ \\
\hline NS & Ecology & 7 & Australia, Switzerland, United States \\
\hline SS & Economics & 36 & $\begin{array}{l}\text { Australia, Canada, China, Germany, Singapore, Switzerland, United King- } \\
\text { dom, United States }\end{array}$ \\
\hline SS & Education & 13 & Australia, Canada, Finland, United Kingdom, United States \\
\hline EG & Electrical \& Electronic Engineering & 22 & Australia, China, Singapore, Switzerland, United Kingdom, United States \\
\hline EG & Energy Science \& Engineering & 5 & Australia, United Kingdom, United States \\
\hline EG & Environmental Science \& Engineering & 16 & Australia, Canada, China, Germany, United Kingdom, United States \\
\hline SS & Finance & 24 & Australia, Canada, China, Germany, Switzerland, United Kingdom, United States \\
\hline EG & Food Science \& Technology & 2 & Belgium, United States \\
\hline \multirow[t]{2}{*}{ NS } & Geography & 6 & Australia, Belgium, Canada, Germany, United Kingdom \\
\hline & Geological Engineering & 1 & Germany \\
\hline SS & Hospitality \& Tourism Management & 9 & Australia, Canada, Hong Kong, United States \\
\hline LS & Human Biological Sciences & 3 & Japan, United Kingdom \\
\hline SS & Law & 22 & $\begin{array}{l}\text { Australia, Belgium, China, Finland, Germany, Singapore, Switzerland, } \\
\text { United Kingdom, United States }\end{array}$ \\
\hline \multirow[t]{2}{*}{ SS } & Library \& Information Science & 4 & United States \\
\hline & Linguistics & 1 & United Kingdom \\
\hline SS & Management & 26 & $\begin{array}{l}\text { Australia, Belgium, Canada, China, Germany, Netherlands, Singapore, } \\
\text { Switzerland, United Kingdom, United States }\end{array}$ \\
\hline \multirow[t]{2}{*}{ EG } & Marine/Ocean Engineering & 2 & Australia, United States \\
\hline & Marketing & 1 & United States \\
\hline
\end{tabular}




\begin{tabular}{|c|c|c|c|}
\hline $\begin{array}{l}\text { Research } \\
\text { area }\end{array}$ & Academic subject & \# Participants & Countries \\
\hline EG & Materials Science \& Engineering & 29 & $\begin{array}{l}\text { Australia, Canada, China, Germany, Singapore, Switzerland, United King- } \\
\text { dom, United States }\end{array}$ \\
\hline NS & Mathematics & 38 & $\begin{array}{l}\text { Australia, Belgium, China, Germany, Singapore, Switzerland, United King- } \\
\text { dom, United States }\end{array}$ \\
\hline EG & Mechanical Engineering & 28 & $\begin{array}{l}\text { Australia, Canada, China, Germany, Singapore, Switzerland, United King- } \\
\text { dom, United States }\end{array}$ \\
\hline MS & Medical Technology & 1 & Switzerland \\
\hline EG & Metallurgical Engineering & 7 & Australia, Canada, Switzerland \\
\hline EG & Mining \& Mineral Engineering & 2 & Australia, United Kingdom \\
\hline \multirow[t]{2}{*}{ EG } & Nanoscience \& Nanotechnology & 4 & Australia, China, United States \\
\hline & Nuclear Engineering & 1 & United States \\
\hline MS & Nursing & 9 & Australia, Canada, Singapore, United Kingdom, United States \\
\hline NS & Oceanography & 2 & Australia, Germany \\
\hline MS & Pharmacy \& Pharmaceutical Sciences & 11 & Australia, Belgium, Germany, United Kingdom, United States \\
\hline \multirow[t]{2}{*}{ NS } & Physics & 33 & $\begin{array}{l}\text { Australia, Belgium, Finland, Germany, Switzerland, United Kingdom, } \\
\text { United States }\end{array}$ \\
\hline & Political Sciences & 11 & Australia, Canada, China, Netherlands, United Kingdom, United States \\
\hline SS & Psychology & 16 & Australia, Canada, Germany, United Kingdom, United States \\
\hline SS & Public Administration & 2 & Canada, China \\
\hline MS & Public Health & 8 & Australia, Canada, Denmark, Finland, Taiwan, United States \\
\hline EG & Remote Sensing & 3 & Germany, Switzerland, United States \\
\hline \multirow[t]{2}{*}{ SS } & Sociology & 4 & Canada, United States, United Kingdom \\
\hline & Sports Science & 3 & Australia, Canada \\
\hline \multirow[t]{2}{*}{ SS } & Statistics & 20 & Australia, Canada, China, Germany, Switzerland, United Kingdom, United States \\
\hline & Textiles and Clothing & 1 & United States \\
\hline EG & Transportation Science \& Technology & 1 & Australia \\
\hline LS & Veterinary Sciences & 18 & Australia, Belgium, Finland, Switzerland, United Kingdom, United States \\
\hline EG & Water Resources & 4 & Canada, Switzerland, United Kingdom, United States \\
\hline
\end{tabular}

\subsection{Top journals}

The first problem identified relates to the process used to select the journals that make up the list. According to the ranking methodology, these journals are identified after applying a survey to hundreds of participants. However, eight academic subjects (Agricultural Sciences, Biotechnology, Food Science \& Technology, Instruments Science \& Technology, Medical Technology, Oceanography, Telecommunication Engineering, and Transportation Science \& Technology) are assessed without considering this indicator. As previously mentioned, in five of these academic subjects, one could assume that none of the journals proposed by the participants received more than $50 \%$ of the votes. However, it also seems that none of these journals were selected in 2019, which is an alternative criterion used to appoint a journal in case none received over $50 \%$ of the votes.

The second problem is the number of Top journals selected as an indicator for the remaining 46 academic subjects. For 11 of these academic subjects, only one journal was considered a Top journal. This poses a real problem as one journal is not representative of all the research topics that may be associated to one academic subject. Furthermore, in some academic subjects the selected journal published a low proportion of article-type documents within the five-year period. Bewildering was the selection of one of the journals for the academic subject of Sport Science, entitled Medicine and Science in Sports and Exercise, whose content consisted main-
$94.7 \%$ of the documents registered by WoS between 2014-2018 were in English language. Consequently, these limitations raise a question as to whether the Shanghai Global Ranking of Academic Subjects is applying a fair assessment of all higher education institutions. Thus, it is of the uttermost importance to bring researchers from the Global South out of the shadows 
ly of meeting abstracts (89.9\% of all documents published). Not to mention the particular case of Pharmacy \& Pharmaceutical Sciences, where the methodology considers exceptionally the total number of articles and reviews published. However, the solely selected journal mainly publishes reviews. As Table 3 illustrates, both document types make up only $16.3 \%$ of all the documents published by the journal Nature reviews drug discovery.
For 11 academic subjects, only one journal was considered a Top journal. This poses a real problem as one journal is not representative of all the research topics that may be associated to one academic subject

Table 3. List of top journals as determined by the surveyed participants. For each journal, the proportion of votes toward a specific journal and the proportion of articles and reviews published is provided.

* indicates that these parameters were not estimated as its indexation was discontinued in 2013 due to a journal title change.

\begin{tabular}{|c|c|c|c|c|c|}
\hline Academic subject & Title & ISSN & $\begin{array}{c}\% \\
\text { voted }\end{array}$ & $\begin{array}{c}\% \\
\text { articles }\end{array}$ & $\begin{array}{c}\% \\
\text { reviews }\end{array}$ \\
\hline \multirow{4}{*}{ Aerospace Engineering } & Journal of spacecraft and rockets & $0022-4650$ & $83 \%$ & $98 \%$ & $0.4 \%$ \\
\hline & AIAA journal & $0001-1452$ & $83 \%$ & $99 \%$ & $0.1 \%$ \\
\hline & Journal of propulsion and power & $0748-4658$ & $50 \%$ & $98 \%$ & $0.2 \%$ \\
\hline & Journal of aircraft & 0021-8669 & $50 \%$ & $98 \%$ & $0.0 \%$ \\
\hline \multirow{5}{*}{ Agricultural Economics } & American journal of agricultural economics & 0002-9092 & $100 \%$ & $89 \%$ & $0.0 \%$ \\
\hline & European review of agricultural economics & 0165-1587 & $75 \%$ & $90 \%$ & $0.0 \%$ \\
\hline & Journal of environmental economics and management & 0095-0696 & $75 \%$ & $97 \%$ & $0.0 \%$ \\
\hline & Land economics & 0023-7639 & $50 \%$ & $99 \%$ & $0.0 \%$ \\
\hline & Agricultural economics & $0169-5150$ & $50 \%$ & $99 \%$ & $0.3 \%$ \\
\hline \multirow{6}{*}{ Atmospheric Science } & Nature climate change & $1758-678 \mathrm{X}$ & $83 \%$ & $45 \%$ & $2.0 \%$ \\
\hline & Journal of climate & 0894-8755 & $67 \%$ & $97 \%$ & $0.8 \%$ \\
\hline & Climate dynamics & 0930-7575 & $50 \%$ & $98 \%$ & $0.0 \%$ \\
\hline & Bulletin of the American Meteorological Society & 0003-0007 & $50 \%$ & $76 \%$ & $0.5 \%$ \\
\hline & Journal of geophysical research-atmospheres & $2169-897 X$ & $50 \%$ & $99 \%$ & $0.3 \%$ \\
\hline & Atmospheric chemistry and physics & $1680-7316$ & $33 \%$ & $99 \%$ & $0.3 \%$ \\
\hline \multirow{5}{*}{ Automation \& Control } & Automatica & 0005-1098 & $82 \%$ & $98 \%$ & $0.0 \%$ \\
\hline & IEEE transactions on automatic control & 0018-9286 & $82 \%$ & $99 \%$ & $0.0 \%$ \\
\hline & SIAM journal on control and optimization & 0363-0129 & $55 \%$ & $100 \%$ & $0.0 \%$ \\
\hline & International journal of robotics research & 0278-3649 & $55 \%$ & $96 \%$ & $0.0 \%$ \\
\hline & IEEE transactions on robotics & 1552-3098 & $55 \%$ & $99 \%$ & $0.0 \%$ \\
\hline Biological Sciences & Cell & 0092-8674 & $61 \%$ & $61 \%$ & $7.0 \%$ \\
\hline Biomedical Engineering & Biomaterials & 0142-9612 & $53 \%$ & $96 \%$ & $3.8 \%$ \\
\hline \multirow{3}{*}{ Business Administration } & Journal of consumer research & 0093-5301 & $38 \%$ & $93 \%$ & $0.8 \%$ \\
\hline & Journal of marketing research & 0022-2437 & $31 \%$ & $94 \%$ & $1.0 \%$ \\
\hline & Journal of marketing & $0022-2429$ & $31 \%$ & $94 \%$ & $0.9 \%$ \\
\hline \multirow{2}{*}{ Chemical Engineering } & Industrial \& engineering chemistry research & 0888-5885 & $56 \%$ & $97 \%$ & $1.7 \%$ \\
\hline & Energy \& environmental science & $1754-5692$ & $52 \%$ & $85 \%$ & $11.2 \%$ \\
\hline \multirow{4}{*}{ Chemistry } & Journal of the American Chemical Society & $0002-7863$ & $83 \%$ & $97 \%$ & $0.7 \%$ \\
\hline & Angewandte Chemie-international edition & $1433-7851$ & $75 \%$ & $93 \%$ & $3.5 \%$ \\
\hline & Nature chemistry & $1755-4330$ & $69 \%$ & $59 \%$ & $1.5 \%$ \\
\hline & Nature materials & $1476-1122$ & $36 \%$ & $53 \%$ & $2.3 \%$ \\
\hline Civil Engineering & Journal of structural engineering & 0733-9445 & $53 \%$ & $94 \%$ & $0.8 \%$ \\
\hline \multirow{2}{*}{ Clinical Medicine } & New England Journal of medicine & $0028-4793$ & $92 \%$ & $19 \%$ & $3.0 \%$ \\
\hline & Lancet & 0140-6736 & $77 \%$ & $12 \%$ & $2.6 \%$ \\
\hline \multirow{5}{*}{ Communication } & Journal of communication & 0021-9916 & $100 \%$ & $69 \%$ & $1.4 \%$ \\
\hline & Communication research & 0093-6502 & $78 \%$ & $96 \%$ & $3.8 \%$ \\
\hline & Human communication research & 0360-3989 & $78 \%$ & $98 \%$ & $1.5 \%$ \\
\hline & New media \& society & $1461-4448$ & $56 \%$ & $78 \%$ & $2.8 \%$ \\
\hline & Communication theory & $1050-3293$ & $44 \%$ & $82 \%$ & $3.1 \%$ \\
\hline Dentistry \& Oral Sciences & Journal of dental research & $0022-0345$ & $90 \%$ & $75 \%$ & $14.9 \%$ \\
\hline
\end{tabular}




\begin{tabular}{|c|c|c|c|c|c|}
\hline Academic subject & Title & ISSN & $\begin{array}{c}\% \\
\text { voted }\end{array}$ & $\begin{array}{c}\% \\
\text { articles }\end{array}$ & $\begin{array}{c}\% \\
\text { reviews }\end{array}$ \\
\hline \multirow{4}{*}{ Earth Sciences } & Earth and planetary science letters & $0012-821 X$ & $58 \%$ & $97 \%$ & $0.0 \%$ \\
\hline & Geophysical research letters & $0094-8276$ & $58 \%$ & $99 \%$ & $0.0 \%$ \\
\hline & Nature geoscience & $1752-0894$ & $58 \%$ & $57 \%$ & $2.0 \%$ \\
\hline & Geochimica et cosmochimica acta & 0016-7037 & $38 \%$ & $96 \%$ & $0.0 \%$ \\
\hline \multirow{3}{*}{ Ecology } & Ecology letters & $1461-023 x$ & $100 \%$ & $85 \%$ & $9.5 \%$ \\
\hline & Trends in ecology \& evolution & 0169-5347 & $71 \%$ & $11 \%$ & $46.4 \%$ \\
\hline & Annual review of ecology evolution and systematics & $1543-592 X$ & $71 \%$ & $0 \%$ & $100.0 \%$ \\
\hline \multirow{5}{*}{ Economics } & Econometrica & $0012-9682$ & $92 \%$ & $95 \%$ & $0.0 \%$ \\
\hline & American economic review & $0002-8282$ & $81 \%$ & $95 \%$ & $0.0 \%$ \\
\hline & Journal of political economy & $0022-3808$ & $75 \%$ & $96 \%$ & $1.2 \%$ \\
\hline & Quarterly journal of economics & $0033-5533$ & $72 \%$ & $98 \%$ & $0.0 \%$ \\
\hline & Review of economic studies & $0034-6527$ & $72 \%$ & $97 \%$ & $0.4 \%$ \\
\hline \multirow{6}{*}{ Education } & American educational research journal & $0002-8312$ & $77 \%$ & $93 \%$ & $5.3 \%$ \\
\hline & Review of educational research & $0034-6543$ & $54 \%$ & $57 \%$ & $41.1 \%$ \\
\hline & Educational researcher & 0013-189X & $46 \%$ & $73 \%$ & $15.7 \%$ \\
\hline & Journal of research in science teaching & $0022-4308$ & $31 \%$ & $94 \%$ & $0.0 \%$ \\
\hline & Journal of teacher education & $0022-4871$ & $31 \%$ & $83 \%$ & $2.3 \%$ \\
\hline & Teaching and teacher education & 0742-051X & $31 \%$ & $94 \%$ & $4.3 \%$ \\
\hline Electrical \& Electronic Engineering & Proceedings of the IEEE & 0018-9219 & $55 \%$ & $73 \%$ & $1.9 \%$ \\
\hline \multirow{2}{*}{ Energy Science \& Engineering } & Energy \& environmental science & $1754-5692$ & $80 \%$ & $85 \%$ & $11.2 \%$ \\
\hline & Advanced energy materials & $1614-6832$ & $60 \%$ & $90 \%$ & $8.2 \%$ \\
\hline Environmental Science \& Engineering & Environmental science \& technology & 0013-936X & $94 \%$ & $91 \%$ & $2.1 \%$ \\
\hline \multirow{3}{*}{ Finance } & Journal of finance & $0022-1082$ & $79 \%$ & $96 \%$ & $0.0 \%$ \\
\hline & Journal of financial economics & 0304-405X & $75 \%$ & $99 \%$ & $0.0 \%$ \\
\hline & Review of financial studies & 0893-9454 & $75 \%$ & $96 \%$ & $0.2 \%$ \\
\hline \multirow{7}{*}{ Geography } & Progress in human geography & $0309-1325$ & $67 \%$ & $66 \%$ & $6.2 \%$ \\
\hline & Annals of the Association of American Geographers & $0004-5608$ & $67 \%$ & $94 \%$ & $1.5 \%$ \\
\hline & Global environmental change-human and policy dimensions & 0959-3780 & $50 \%$ & $97 \%$ & $1.4 \%$ \\
\hline & Journal of rural studies & $0743-0167$ & $50 \%$ & $95 \%$ & $1.9 \%$ \\
\hline & Political geography & $0962-6298$ & $50 \%$ & $78 \%$ & $2.4 \%$ \\
\hline & Transactions of the Institute of British Geographers & 0020-2754 & $50 \%$ & $95 \%$ & $2.1 \%$ \\
\hline & Urban geography & $0272-3638$ & $33 \%$ & $72 \%$ & $2.5 \%$ \\
\hline \multirow{6}{*}{$\begin{array}{l}\text { Hospitality \& Tourism } \\
\text { Management }\end{array}$} & Annals of tourism research & $0160-7383$ & $78 \%$ & $55 \%$ & $1.0 \%$ \\
\hline & International journal of hospitality management & $0278-4319$ & $78 \%$ & $89 \%$ & $3.9 \%$ \\
\hline & International journal of contemporary hospitality management & 0959-6119 & $67 \%$ & $90 \%$ & $6.4 \%$ \\
\hline & Tourism management & 0261-5177 & $67 \%$ & $85 \%$ & $1.7 \%$ \\
\hline & Journal of travel research & $0047-2875$ & $56 \%$ & $92 \%$ & $7.4 \%$ \\
\hline & Journal of hospitality \& tourism research & $1096-3480$ & $44 \%$ & $89 \%$ & $8.2 \%$ \\
\hline \multirow{3}{*}{ Human Biological Sciences } & Nature immunology & $1529-2908$ & $67 \%$ & $45 \%$ & $7.8 \%$ \\
\hline & Immunity & $1074-7613$ & $67 \%$ & $57 \%$ & $8.2 \%$ \\
\hline & Nature medicine & $1078-8956$ & $67 \%$ & $50 \%$ & $2.4 \%$ \\
\hline \multirow{2}{*}{ Law } & Harvard law review & 0017-811X & $59 \%$ & $73 \%$ & $0.6 \%$ \\
\hline & Yale law journal & 0044-0094 & $59 \%$ & $74 \%$ & $3.1 \%$ \\
\hline \multirow{6}{*}{ Library \& Information Science } & MIS quarterly & $0276-7783$ & $75 \%$ & $444 \%$ & $5.0 \%$ \\
\hline & $\begin{array}{l}\text { Journal of the American Society for Information Science and } \\
\text { Technology }\end{array}$ & $1532-2882$ & $75 \%$ & * & * \\
\hline & Journal of the American Medical Informatics Association & $1067-5027$ & $50 \%$ & $82 \%$ & $8.3 \%$ \\
\hline & Government information quarterly & $0740-624 X$ & $50 \%$ & $84 \%$ & $3.2 \%$ \\
\hline & Information \& management & $0378-7206$ & $50 \%$ & $95 \%$ & $3.2 \%$ \\
\hline & Journal of information science & $0165-5515$ & $50 \%$ & $97 \%$ & $0.7 \%$ \\
\hline
\end{tabular}




\begin{tabular}{|c|c|c|c|c|c|}
\hline Academic subject & Title & ISSN & $\begin{array}{c}\% \\
\text { voted }\end{array}$ & $\begin{array}{c}\% \\
\text { articles }\end{array}$ & $\begin{array}{l}\% \\
\text { reviews }\end{array}$ \\
\hline \multirow{6}{*}{ Management } & Academy of Management journal & $0001-4273$ & $70 \%$ & $93 \%$ & $0.0 \%$ \\
\hline & Management science & 0025-1909 & $67 \%$ & $98 \%$ & $0.1 \%$ \\
\hline & Academy of Management review & $0363-7425$ & $67 \%$ & $64 \%$ & $0.9 \%$ \\
\hline & Strategic management journal & 0143-2095 & $63 \%$ & $93 \%$ & $3.2 \%$ \\
\hline & Organization science & $1047-7039$ & $59 \%$ & $97 \%$ & $0.0 \%$ \\
\hline & Administrative science quarterly & 0001-8392 & $48 \%$ & $49 \%$ & $1.9 \%$ \\
\hline Marine/Ocean Engineering & Applied ocean research & 0141-1187 & $100 \%$ & $99 \%$ & $1.1 \%$ \\
\hline \multirow{2}{*}{ Materials Science \& Engineering } & Nature materials & $1476-1122$ & $66 \%$ & $53 \%$ & $2.3 \%$ \\
\hline & Advanced materials & 0935-9648 & $59 \%$ & $92 \%$ & $6.9 \%$ \\
\hline \multirow{3}{*}{ Mathematics } & Annals of mathematics & $0003-486 \mathrm{X}$ & $72 \%$ & $97 \%$ & $0.0 \%$ \\
\hline & Inventiones mathematicae & 0020-9910 & $49 \%$ & $97 \%$ & $0.0 \%$ \\
\hline & Journal of the American Mathematical Society & 0894-0347 & $46 \%$ & $100 \%$ & $0.0 \%$ \\
\hline \multirow{9}{*}{ Mechanical Engineering } & Journal of fluid mechanics & $0022-1120$ & $43 \%$ & $99 \%$ & $0.1 \%$ \\
\hline & International journal of heat and mass transfer & $0017-9310$ & $23 \%$ & $97 \%$ & $1.8 \%$ \\
\hline & Journal of the mechanics and physics of solids & $0022-5096$ & $20 \%$ & $97 \%$ & $0.3 \%$ \\
\hline & Combustion and flame & $0010-2180$ & $20 \%$ & $99 \%$ & $0.0 \%$ \\
\hline & Journal of sound and vibration & $0022-460 x$ & $17 \%$ & $97 \%$ & $0.5 \%$ \\
\hline & IEEE-ASME transactions on mechatronics & $1083-4435$ & $17 \%$ & $98 \%$ & $0.4 \%$ \\
\hline & Proceedings of the Combustion Institute & $1540-7489$ & $13 \%$ & $99 \%$ & $1.0 \%$ \\
\hline & Journal of engineering for gas turbines and power & $0742-4795$ & $13 \%$ & $99 \%$ & $0.4 \%$ \\
\hline & Journal of turbomachinery-transactions of the ASME & 0889-504X & $13 \%$ & $99 \%$ & $0.2 \%$ \\
\hline \multirow{4}{*}{ Metallurgical Engineering } & Acta materialia & $1359-6454$ & $71 \%$ & $99 \%$ & $0.0 \%$ \\
\hline & Scripta materialia & $1359-6462$ & $43 \%$ & $98 \%$ & $0.1 \%$ \\
\hline & Corrosion science & 0010-938X & $43 \%$ & $98 \%$ & $1.1 \%$ \\
\hline & $\begin{array}{l}\text { Metallurgical and materials transactions A-Physical metallurgy } \\
\text { and materials science }\end{array}$ & $1073-5623$ & $43 \%$ & $97 \%$ & $0.0 \%$ \\
\hline Mining \& Mineral Engineering & International journal of rock mechanics and mining sciences & $1365-1609$ & $100 \%$ & $99 \%$ & $0.0 \%$ \\
\hline \multirow{7}{*}{ Nanoscience \& Nanotechnology } & Advanced materials & 0935-9648 & $100 \%$ & $92 \%$ & $6.9 \%$ \\
\hline & Nano letters & $1530-6984$ & $100 \%$ & $98 \%$ & $0.1 \%$ \\
\hline & Advanced functional materials & $1616-301 X$ & $75 \%$ & $97 \%$ & $1.6 \%$ \\
\hline & ACS nano & $1936-0851$ & $75 \%$ & $96 \%$ & $1.0 \%$ \\
\hline & Nature nanotechnology & $1748-3387$ & $75 \%$ & $53 \%$ & $2.9 \%$ \\
\hline & Nano today & $1748-0132$ & $50 \%$ & $15 \%$ & $48.3 \%$ \\
\hline & Small & $1613-6810$ & $50 \%$ & $91 \%$ & $8.3 \%$ \\
\hline \multirow{2}{*}{ Nursing } & International journal of nursing studies & 0020-7489 & $89 \%$ & $57 \%$ & $28.1 \%$ \\
\hline & Research in nursing \& health & $0160-6891$ & $67 \%$ & $71 \%$ & $2.5 \%$ \\
\hline $\begin{array}{l}\text { Pharmacy \& Pharmaceutical } \\
\text { Sciences }\end{array}$ & Nature reviews drug discovery & $1474-1776$ & $64 \%$ & $3 \%$ & $12.9 \%$ \\
\hline Physics & Physical review letters & $0031-9007$ & $73 \%$ & $96 \%$ & $0.0 \%$ \\
\hline \multirow{4}{*}{ Political Sciences } & American political science review & 0003-0554 & $82 \%$ & $91 \%$ & $0.3 \%$ \\
\hline & World politics & $0043-8871$ & $73 \%$ & $89 \%$ & $5.0 \%$ \\
\hline & International organization & $0020-8183$ & $64 \%$ & $95 \%$ & $1.8 \%$ \\
\hline & American journal of political science & $0092-5853$ & $45 \%$ & $97 \%$ & $0.3 \%$ \\
\hline \multirow{4}{*}{ Psychology } & Psychological science & 0956-7976 & $69 \%$ & $88 \%$ & $0.0 \%$ \\
\hline & Psychological bulletin & 0033-2909 & $56 \%$ & $67 \%$ & $18.1 \%$ \\
\hline & Psychological review & 0033-295X & $50 \%$ & $88 \%$ & $0.0 \%$ \\
\hline & Trends in cognitive sciences & $1364-6613$ & $44 \%$ & $57 \%$ & $0.0 \%$ \\
\hline Public Administration & Public administration review & $0033-3352$ & $100 \%$ & $41 \%$ & $0.7 \%$ \\
\hline
\end{tabular}




\begin{tabular}{|c|c|c|c|c|c|}
\hline Academic subject & Title & ISSN & $\begin{array}{c}\% \\
\text { voted }\end{array}$ & $\begin{array}{c}\% \\
\text { articles }\end{array}$ & $\begin{array}{l}\% \\
\text { reviews }\end{array}$ \\
\hline \multirow{3}{*}{ Public Health } & International journal of epidemiology & 0300-5771 & $63 \%$ & $40 \%$ & $1.8 \%$ \\
\hline & Environmental health perspectives & $0091-6765$ & $50 \%$ & $64 \%$ & $5.5 \%$ \\
\hline & Annual review of public health & $0163-7525$ & $38 \%$ & $0 \%$ & $95.1 \%$ \\
\hline \multirow{3}{*}{ Remote Sensing } & IEEE transactions on geoscience and remote sensing & 0196-2892 & $100 \%$ & $99 \%$ & $0.0 \%$ \\
\hline & Remote sensing of environment & $0034-4257$ & $100 \%$ & $97 \%$ & $1.3 \%$ \\
\hline & ISPRS journal of photogrammetry and remote sensing & 0924-2716 & $67 \%$ & $95 \%$ & $3.2 \%$ \\
\hline \multirow{2}{*}{ Sociology } & American journal of sociology & $0002-9602$ & $100 \%$ & $20 \%$ & $0.0 \%$ \\
\hline & American sociological review & $0003-1224$ & $100 \%$ & $85 \%$ & $10.2 \%$ \\
\hline \multirow{3}{*}{ Sports Science } & Journal of applied physiology & $8750-7587$ & $67 \%$ & $71 \%$ & $7.3 \%$ \\
\hline & Medicine and science in sports and exercise & 0195-9131 & $67 \%$ & $9 \%$ & $0.0 \%$ \\
\hline & Journal of sports sciences & $0264-0414$ & $67 \%$ & $95 \%$ & $1.6 \%$ \\
\hline \multirow{4}{*}{ Statistics } & Annals of statistics & $0090-5364$ & $90 \%$ & $95 \%$ & $0.0 \%$ \\
\hline & Journal of the American Statistical Association & 0162-1459 & $90 \%$ & $84 \%$ & $1.3 \%$ \\
\hline & $\begin{array}{l}\text { Journal of the Royal Statistical Society Series B-Statistical } \\
\text { methodology }\end{array}$ & $1369-7412$ & $70 \%$ & $96 \%$ & $1.6 \%$ \\
\hline & Biometrika & 0006-3444 & $60 \%$ & $98 \%$ & $0.0 \%$ \\
\hline \multirow{2}{*}{ Veterinary Sciences } & Veterinary microbiology & 0378-1135 & $61 \%$ & $94 \%$ & $2.8 \%$ \\
\hline & Veterinary research & $0928-4249$ & $44 \%$ & $91 \%$ & $8.2 \%$ \\
\hline \multirow{2}{*}{ Water Resources } & Water resources research & 0043-1397 & $100 \%$ & $94 \%$ & $1.5 \%$ \\
\hline & Journal of hydrology & $0022-1694$ & $50 \%$ & $96 \%$ & $1.8 \%$ \\
\hline
\end{tabular}

Unexpectedly, the Journal of the American Society for Information Science and Technology (ISSN 1532-2882) was voted among the Top 100 even though this journal no longer exists as it changed its title in 2014 (it is currently known as Journal of the Association for Information Science and Technology) as well as its ISSN (2330-1635). While some of the researchers that voted for this journal may still retain in their mind the old journal title, the fact that the former ISSN was included in the list -instead of the new one- was disconcerting. What data was collected from this journal? A Web of Science search query using the former journal title or ISSN only listed records up to the year 2013, an outcome that should have raised red flags. Another option is that the authors of the ranking used the current journal title or ISSN to collect the "article"-type documents but did not update this information in the Top journals list. Either way, such errors distort the quantitative assessment and reliability of the Top indicator.

A major and valid concern is the reason why these journals are chosen by the participants. Besides being first quartile journals, their other common attribute is that all the journals publish in English-language. But what makes these journals Top? Is it their citation level or impact factor? A quick analysis of the Journal Citation Reports revealed that plenty of other journals surpass the citation level and impact factor of Top journals. Conceivably, these journals may have been selected due to top-of-mind associations based on the participant's own experience with the journal. A simplified, clear explanation of the full process by which Top journals have been selected would enlighten all users of the Shanghai Global Ranking of Academic

A simplified, clear explanation of the full process by which Top journals have been selected would enlighten all users of the Shanghai Global Ranking of Academic Subjects Subjects.

\section{Conclusions}

For many years, global university rankings have been acknowledged has a valid instrument to compare universities worldwide. Unfortunately, most users focus primarily on the ranking results and not the methodology used to elaborate the ranking. The results of this study show that the methodology currently used by the Shanghai Global Ranking of Academic Subjects presents several issues, which negatively affect a large proportion of universities around the world. Needless to say, if the Shanghai Global Ranking of Academic Subjects is meant to be global, it needs to expand its surveys to countries located in the Global South. This will not only assure a fair country representation, but it will also contribute to a more diverse collection of data that would drive an improved understanding on how universities succeed at certain academic subjects. It is important to note that in a globalized context, the performance of one university is not autonomous as it depends on how other universities are performing too.

Lastly, it is important to emphasize that while this study was possible due to the methodology supplied by the ranking provider on their website, there is a need for more clarity. By providing more information, perhaps some of these incongruities could be easily avoided. 


\section{References}

Billaut, Jean-Charles; Bouyssou, Denis; Vincke, Philippe (2010). "Should you believe in the Shanghai ranking? An MCDM view". Scientometrics, v. 84, n. 1, pp. 237-263.

https://doi.org/10.1007/s11192-009-0115-x

DORA (2015). San Francisco declaration on research assessment.

https://sfdora.org/read

Fauzi, Muhammad-Ashraf; Tan, Christine-Nya-Ling; Daud, Mahyuddin; Awalludin, Muhammad-Mukhtar-Noor (2020). "University rankings: A review of methodological flaws". Issues in educational research, v. 30, n. 1, pp. 79-96.

http://www.iier.org.au/iier30/fauzi.pdf

Fernández-Cano, Antonio; Curiel-Marín, Elvira; Torralbo-Rodríguez, Manuel; Vallejo-Ruiz, Mónica (2018). “Questioning the Shanghai Ranking methodology as a tool for the evaluation of universities: an integrative review". Scientometrics, v. 116, n. 3, pp. 2069-2083.

https://doi.org/10.1007/s11192-018-2814-7

Fernández-Tuesta, Esteban; García-Zorita, Carlos; Romera-Ayllón, Rosario; Sanz-Casado, Elías (2019). “Does a country/ region's economic status affect its universities presence in international rankings?". Journal of data and information science, v. 4, n. 2, pp. 56-78.

https://doi.org/10.2478/jdis-2019-0009

Florian, Razvan V. (2007). "Irreproducibility of the results of the Shanghai academic ranking of world universities". Scientometrics, v. 72, n. 1, pp. 25-32.

https://doi.org/10.1007/s11192-007-1712-1

González-Riaño, María-Guadalupe; Repiso, Rafael; Delgado-López-Cózar, Emilio (2014). “Repercusión de los rankings universitarios en la prensa española". Revista española de documentación científica, v. 37, n. 3, e055.

https://doi.org/10.3989/redc.2014.3.1128

Kabeer, Naila (2005). “Gender equality and women's empowerment: A critical analysis of the third millennium development goal". Gender and development, v. 13, n. 1, pp. 13-24.

https://doi.org/10.1080/13552070512331332273

Kehm, Barbara M. (2014). "Global university rankings. Impacts and unintended side effects". European journal of education, v. 49, n. 1, pp. 102-112.

https://doi.org/10.1111/ejed.12064

Krauskopf, Erwin (2011). "The unforeseen impact of meeting abstracts on cancer research". Annals of oncology, v. 22, n. 10, 2342.

https://doi.org/10.1093/annonc/mdr406

Krauskopf, Erwin (2013). "Standardization of the institutional address". Scientometrics, v. 94, pp. 1313-1315.

https://doi.org/10.1007/s11192-012-0852-0

Marginson, Simon (2014). "University rankings and social science". European journal of education, v. 49, n. 1, pp. $45-59$. https://doi.org/10.1111/ejed.12061

Marginson, Simon; Van-der-Wende, Marijk (2007) "To rank or to be ranked: The impact of global rankings in higher education". Journal of studies in international education, v. 11, n. 3/4, pp. 306-329.

https://doi.org/10.1177/1028315307303544

Mongeon, Philippe; Paul-Hus, Adèle (2015). "The journal coverage of Web of Science and Scopus: a comparative analysis". Scientometrics, v. 106, pp. 213-228.

https://doi.org/10.1007/s11192-015-1765-5

Olcay, Gokcen-Arkali; Bulu, Melih (2017). "Is measuring the knowledge creation of universities possible? A review of university rankings". Technological forecasting \& social change, v. 123, pp. 153-160.

https://doi.org/10.1016/j.techfore.2016.03.029

Ordóñez-Matamoros, Gonzalo; Vernot-López, Michelle; Moreno-Mattar, Ornella; Orozco, Luis-Antonio (2020). “Exploring the effects of North-South and South-South research collaboration in emerging economies, the Colombian case". Review of policy research, v. 37, n. 2, pp. 174-200.

https://doi.org/10.1111/ropr.12378

Pandiella-Dominique, Andrés; Moreno-Lorente, Luis; García-Zorita, José-Carlos; Sanz-Casado, Elías (2018). “Modelo de estimación de los indicadores del Academic Ranking of World Universities (Shanghai Ranking) scores". Revista española de documentación científica, v. 41, n. 2, e204.

https://doi.org/10.3989/redc.2018.2.1462 
Pusser, Brian; Marginson, Simon (2013). "University rankings in critical perspective”. The journal of higher education, v. 84, n. 4, pp. 544-568.

https://doi.org/10.1353/jhe.2013.0022

Ridgeway, Cecilia L. (2011). Framed by gender: How gender inequality persists in the modern world. United Kingdom. Oxford University Online. ISBN: 9780199755783

Rochmyaningsih, Dyna (2018). "Showcase scientists from the Global South". Nature, v. 553, 251. https://doi.org/10.1038/d41586-018-00662-w

Sauder, Michael; Espeland, Wendy-Nelson (2009). "The discipline of rankings: tight coupling and organization change". American sociological review, v. 74, n. 1, pp. 63-82. https://doi.org/10.1177/000312240907400104

Snowball, Jen D.; Shackleton, Charlie M. (2018). "Factors enabling and constraining research in a small research-intensive South African university". Research evaluation, v. 27, n. 2, pp. 119-131.

https://doi.org/10.1093/reseval/rvy002

Stoet, Gijsbert; Geary, David C. (2018). "The gender-equality paradox in science, technology, engineering, and mathematics education". Psychological science, v. 29, n. 4, pp. 581-593.

https://doi.org/10.1177/0956797617741719

Van-der-Stocken, Tom; Hugé, Jean; Deboelpaep, Evelien; Vanhove, Maarten P. M.; Janssens-de-Bisthoven, Luc; Koedam, Nico (2016). "Academic capacity building: holding up the mirror". Scientometrics, v. 106, n. 3, pp. $1277-1280$. https://doi.org/10.1007/s11192-015-1811-3

Van-der-Wende, Marijk; Westerheijden, Don (2009). "Rankings and classifications: the need for a multidimensional approach". In: Van-Vught, Frans (ed.). Mapping the higher education landscape. Towards a European classification of higher education. The Netherlands: Springer, pp. 71-87.

https://doi.org/10.1007/978-90-481-2249-3_5

Van-Leeuwen, Thed; Costas, Rodrigo; Calero-Medina, Clara; Visser, Martijn S. (2013). "The role of editorial material in bibliometric performance assessments". Scientometrics, v. 95, pp. 817-828.

https://doi.org/10.1007/s11192-012-0904-5

Van-Leeuwen, Thed N.; Moed, Henk F.; Tijseen, Robert J. W.; Visser, Martijn S.; Van-Raan, Anthony F. J. (2001). “Language biases in the coverage of the Science Citation Index and its consequences for international comparisons of national research performance". Scientometrics, v. 51, pp. 335-346.

https://doi.org/10.1023/A:1010549719484

Van-Rann, Anthony F. J (2005). "Fatal attraction: Conceptual and methodological problems in the ranking of universities by bibliometric methods". Scientometrics, v. 62, pp. 133-143.

https://doi.org/10.1007/s11192-005-0008-6

Wiesmann, Urs; Dayer, Océane 2019. "Research for Sustainable development goals". GAIA, v. 28, n. 2, pp. 88-89. https://doi.org/10.14512/gaia.28.2.4

Williams, Ross; Van-Dyke, Nina 2008. "Reputation and reality: Ranking major disciplines in Australian universities". Higher education, v. 56, n. 1, pp. 1-28.

https://doi.org/10.1007/s10734-007-9086-0

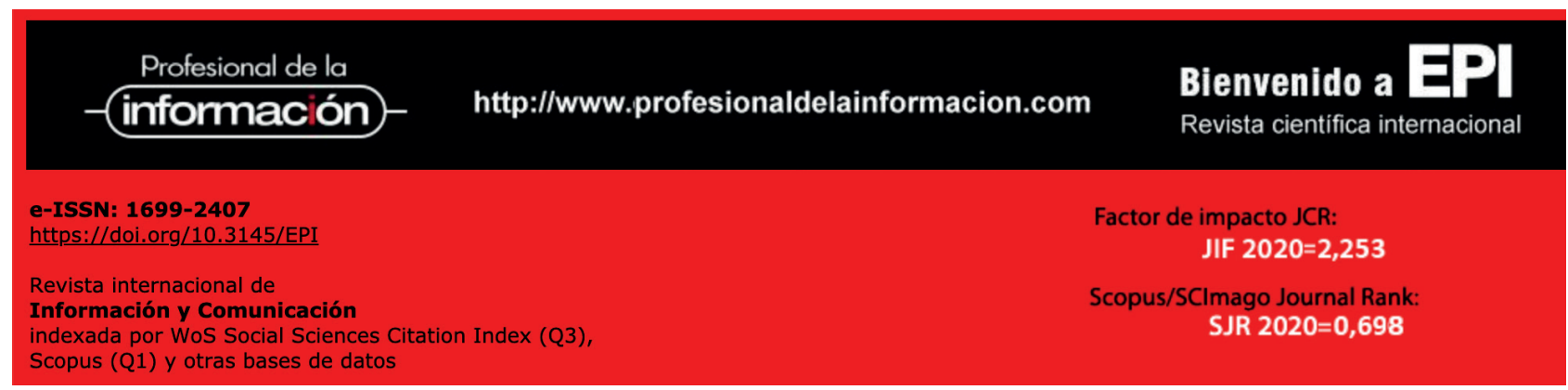

